\title{
VARIABLE EFFECT OF STEAM INJECTION LEVEL ON BEEF MUSCLES: SEMITENDINOSUS AND BICEPS FEMORIS COOKED IN CONVECTION-STEAM OVEN*
}

\author{
Marzena Zając ${ }^{\bowtie}$, Sławomir Kącik, Krystyna Palka, Paweł Widurek \\ Department of Animal Products Technology, University of Agriculture in Krakow \\ Balicka 122, 30-149 Kraków, Poland
}

\begin{abstract}
Background. Combi ovens are used very often in restaurants to heat up food. According to the producers the equipment allows to cook meat portions which are more tender and flavoursome comparing to conventional cooking techniques.

Materials and methods. Beef steaks from muscles semitendinosus and biceps femoris were cooked in convection-steam oven at three humidity levels: 10,60 and 100\%. Chemical composition, including total and insoluble collagen content and cook losses were analysed along with the texture and colour parameters. Results. M. biceps femoris was the hardest and the most chewy at 100\% steam saturation level and hardness measured for $m$. semitendinosus was the lowest at $10 \%$ of vapour injection. Changing the steam conditions in the oven chamber did not affect the detectable colour differences of $m$. biceps femoris, but it was significant for $m$. semitendinosus. Applying 100\% steam saturation caused higher cook losses and the increase of insoluble collagen fractions in both analysed muscles.

Conclusions. The results are beneficial for caterers using steam-convection ovens in terms of providing evidence that the heating conditions should be applied individually depending on the muscle used. The tenderness of $m$. semitendinosus muscle cooked at $10 \%$ steam saturation level was comparable to the tenderness obtained for the same muscle aged for 10 days and cooked with $100 \%$ steam saturation. Steaks from m. biceps femoris muscle should be cooked with maximum $60 \%$ saturation level to obtain higher tenderness.
\end{abstract}

Key words: beef, convection-steam oven, meat quality, tenderness, colour

\section{INTRODUCTION}

The food processing techniques have developed in recent years and the driving force of this development was consumers' safety and their demand for high-quality products including novelty foods. On the other hand, the industry is interested in cost effective technologies which would allow to keep the system automated, to manufacture consistent quality products, to control the whole process and finally to satisfy consumers (Awuah et al., 2007).

Steam - convection ovens or "combi" ovens are commonly used in restaurants and various catering points. According to the oven producers, that equipment

\footnotetext{
『mazajac@ar.krakow.pl, phone +48126624786

*The samples were prepared in the cooperation with the restaurant "Smak Ukraiński" in Krakow.

This research work was supported by the Ministry of Science and Higher Education, Poland (DS-3700/WTŻ). 
Zając, M., Kącik, S., Palka, K., Widurek, P. (2015). Variable effect of steam injection level on beef muscles: semitendinosus and biceps femoris cooked in convection-steam oven. Acta Sci. Pol. Technol. Aliment., 14(4), 303-312. DOI: 10.17306/J.AFS.2015.4.31

is a wonderful tool for cooking healthy and tasty dishes with minimum energy and time required. It allows to create number of recipes of consistent quality. It gives possibility to cook with hot steam, grill, bake, roast or braise. Thanks to such an oven it is possible to save fat, water, and to decrease the cook losses. It saves time and space in the restaurant as there is only one piece of equipment necessary for multiple cooking procedures. In the modern convection-steam ovens it is possible to cook or heat various types of food like meat, vegetables or cakes at the same time, without any smell transfer (Diakun and Zawisza, 2006; Blodgett, n.d.; Dastro, n.d.; Hobart, n.d.). Although the equipment is not a novelty, there is still few publication data showing its effects on various foods.

Beef consumption level is very low in Poland (below $2 \mathrm{~kg} /$ person/year). It was high at the beginning of the 90's of the last century (over $20 \mathrm{~kg} /$ person/year), but due to the changes in law regulations and BSE outburst, the prices of beef increased and it was not as available for consumers as earlier (Kosiecka-Gębska et al., 2010; Verbeke, 2009). As cattle production has always been more concentrated on milk production the Polish beef in general is not of a good quality, which consumers very often associate with tenderness. Ageing is the common practice to improve this quality of meat (Campo et al., 2000; Monson et al., 2005), but it requires time and also working space, which may not be vast, especially in small restaurants.

For cooks in restaurants it is important to prepare good quality food in a relatively short time. Using the steam-convection oven should help, however, the high quality of meat should be kept. Applying proper conditions for preparing meat in a relatively new equipment is a necessary step to obtain a high quality steak. Those conditions are usually not known, as the "combi" ovens are mainly used to heat up the food, including meat. Cooks themselves, try to work out their own good practice in preparing meat. It would be recommended to prepare a set of rules that would be applicable in restaurants for different cuts of meat cooked in convection-steam oven. There are papers in which various conditions in convection-steam ovens were tested. Most of the analysis were conducted on beef and pork roasts, rabbit meat or poultry breasts, but to the best of our knowledge, there is no data on beef steaks prepared in convection-steam oven (Barbanti and Pasquini, 2005; Bowers et al., 2012; Modzelewska-Kapitula et al., 2012; Mora et al., 2011; Zhuang and Savage, 2008). Research conducted on pork revealed that the quality of pork roasted in traditional oven in comparison with pork cooked in convectionsteam oven was similar. The temperature $180^{\circ} \mathrm{C}$ and steam saturation of $40-50 \%$ applied during pork preparation was comparable to fried or roasted meat (Chiavaro et al., 2009; Guzek et al., 2012).

The aim of this study was to compare the eating quality of beef steaks from $\mathrm{m}$. semitendinosus and $m$. biceps femoris muscle prepared in steam-convection oven with variable steam level application. The conditions in which various cuts of meat should be prepared using the convection-steam oven may be valuable for the catering business. Another aspect of this study was to find out, if it would be possible to obtain good quality steaks in the combi oven using non-aged beef.

\section{EXPERIMENTAL}

\section{Materials and cooking methods}

Beef muscles: semitendinosus (ST) and biceps femoris (BF) were purchased from a local retailer $48 \mathrm{~h}$ after slaughter ( 3 of each type). Every muscle was divided into two parts. One part was vacuum packed and stored for another 8 days at $2^{\circ} \mathrm{C}$. The other part was analysed immediately. The muscles were cut perpendicular to muscle fibres ( 3 slices from each muscle for every treatment, each slice was $2.5 \mathrm{~cm}$ thick $\times 3$ muscles $=9$ samples).

Steaks (one from ST and one from BF were placed on a tray (in pairs) in the warmed convection-steam oven (UNOX, Model XV) in the temperature $160^{\circ} \mathrm{C}$ and cooked at $10 \%$ of steam saturation in the oven chamber until obtaining $72^{\circ} \mathrm{C}$ in the geometrical centre. Another pair of steaks was placed in the oven at $60 \%$ steam saturation level and cooked to the same internal temperature and similarly the third pair of steaks was inserted to the oven at $100 \%$ saturation level and cooked as previously. In each case the time necessary to obtain the temperature $72^{\circ} \mathrm{C}$ was approximately 17 minutes. After cooking, steaks were allowed to cool to room temperature for $2 \mathrm{~h}$. The cook loss was calculated by weighing the samples prior and after cooking. The muscles after ageing time (3 steaks for each 
Zając, M., Kącik, S., Palka, K., Widurek, P. (2015). Variable effect of steam injection level on beef muscles: semitendinosus and biceps femoris cooked in convection-steam oven. Acta Sci. Pol. Technol. Aliment., 14(4), 303-312. DOI: 10.17306/J.AFS.2015.4.31

muscle $=9$ samples) were prepared in convectionsteam oven in the same way as the non-aged meat except that the steam conditions applied were only with $100 \%$ saturation level.

\section{Chemical analysis}

Samples after mincing were analysed for water, protein, fat and ash content. Total water content was determined by drying the sample at $105^{\circ} \mathrm{C}$ (PN-ISO1442:2000). Protein content was determined by the Kjeldahl method (PN-75/A-04018). Fat was evaluated by diethyl ether extraction (PN-ISO1444:2000). Ash content was determined by drying and then burning the sample in the muffle furnace (PN-ISO936:2000). Collagen content was measured by hydroxyproline determination according to Polish standard (PN-ISO3496:2000). The collagen content was calculated from hydroxyproline content using coefficient 7.25. Insoluble collagen was extracted after homogenisation of $5 \mathrm{~g}$ meat sample with $24 \mathrm{~cm}^{3}$ of distilled water. Homogenates were heated for $70 \mathrm{~min}$ at $77^{\circ} \mathrm{C}$ and centrifuged. The supernatant was discarded and insoluble collagen content of the sediment was determined as total collagen content described earlier. Insoluble collagen content was calculated as the $\%$ of total collagen.

\section{Texture profile analysis}

The texture profile analysis (TPA) of the samples was conducted as described by Palka (2000). The samples of $14 \mathrm{~mm}$ diameter and $15 \mathrm{~mm}$ length (cut from a muscle along the muscle fibres) were pressed parallel to muscle fibres. Measurements were conducted using a TA-XT2 (Stable Micro Systems) texture analyser with a cylindrical probe of $100 \mathrm{~mm}$ diameter and the following settings: probe travel rate before testing $5 \mathrm{~mm} / \mathrm{s}$, and during and after testing $2 \mathrm{~mm} / \mathrm{s}$, final strain $70 \%$, time interval between first and second stroke $3 \mathrm{~s}$.

\section{Colour assessment CIE L*a*b*}

The colour of all samples was measured using Konica Minolta (CM-3500d) spectrophotometer. The CIE L*, $\mathrm{a}^{*}$, and $\mathrm{b}^{*}$ values, were determined from the mean of six random readings on the cut surface of each steak. Target mask with $8 \mathrm{~mm}$ area was used. The instrument was calibrated on a black glass, then a white enamel tile following the manufacturer's specifications. To examine and relate actual differences $(\Delta E)$ in colour values to visually perceived differences, Euclidean relationship was used:

$$
\Delta E=\sqrt{\Delta L^{2}+\Delta a^{* 2}+\Delta b^{* 2}}
$$

where: $\Delta E-$ equal to the square root of the sum of squares of the differences between $L^{*}, a^{*}$ and $b^{*}$ values.

\section{Statistical analysis}

All data were subjected to analysis of variance (ANOVA) using STATISTICA 10 software. When significant effects were found $(P<0.05)$, the Tukey test was used to locate significant differences between means. The results are presented as average values \pm standard errors.

\section{RESULTS AND DISCUSSION}

\section{Chemical composition and cook losses}

Raw ST muscle contained $626 \mathrm{~g} \cdot \mathrm{kg}^{-1}$ of water, 216 $\mathrm{g} \cdot \mathrm{kg}^{-1}$ of protein and $9 \mathrm{~g} \cdot \mathrm{kg}^{-1}$ of fat. The BF muscle was slightly leaner $\left(8.5 \mathrm{~g} \cdot \mathrm{kg}^{-1}\right.$ of fat $)$ and contained more water $\left(689 \mathrm{~g} \cdot \mathrm{kg}^{-1}\right)$, the protein content was 204 $\mathrm{g} \cdot \mathrm{kg}^{-1}$. The water content was very low in both muscles comparing to other studies, the protein and fat levels were typical for those muscles (Modzelewska-Kapitula et al., 2012; Zając et al., 2011). In cooked samples there was obviously the change of proportions of chemical components due to water and/or fat loss. The cooked ST muscle contained approximately the same amounts of water, protein and fat as the cooked $\mathrm{BF}$. The proximate composition of two analysed muscles is presented in Table 1. The variable steam injection level did not change the ash content in none of the analysed muscles. There was also no difference between those muscles in the amount of mineral substances present in meat. Its mean value was typical for beef $-11 \mathrm{~g} \cdot \mathrm{kg}^{-1}$. There were differences in water and protein content between ST and BF cooked with $100 \%$ of vapour injection. Both muscles cooked with 10 and $60 \%$ saturation level contained more water comparing to those cooked with $100 \%$ steam saturation. It resulted in increased protein content in ST or increased fat content in BF. The intramuscular fat influences the flavour, juiciness and hardness of meat in general and is considered to be crucial for beef steaks' quality (Jeremiach, 1996). In this study there was no 
Zając, M., Kącik, S., Palka, K., Widurek, P. (2015). Variable effect of steam injection level on beef muscles: semitendinosus and biceps femoris cooked in convection-steam oven. Acta Sci. Pol. Technol. Aliment., 14(4), 303-312. DOI: 10.17306/J.AFS.2015.4.31

Table 1. Chemical composition of two muscles cooked in convection oven at 10, 60 and 100\% humidity level (mean values \pm standard errors)

\begin{tabular}{ccccccc}
\hline Muscle type & $\begin{array}{c}\text { Steam saturation } \\
\text { level, \% }\end{array}$ & $\begin{array}{c}\text { Water } \\
\mathrm{g} \cdot \mathrm{kg}^{-1}\end{array}$ & $\begin{array}{c}\text { Fat } \\
\mathrm{g} \cdot \mathrm{kg}^{-1}\end{array}$ & $\begin{array}{c}\text { Protein } \\
\mathrm{g} \cdot \mathrm{kg}^{-1}\end{array}$ & $\begin{array}{c}\text { Ash } \\
\mathrm{g} \cdot \mathrm{kg}^{-1}\end{array}$ & $\begin{array}{c}\text { Collagen } \\
\mathrm{g} \cdot \mathrm{kg}^{-1}\end{array}$ \\
\hline Semitendinosus & 10 & $647.2^{\mathrm{a}} \pm 5.2$ & $13.3^{\mathrm{a}} \pm 0.6$ & $303.0^{\mathrm{a}} \pm 1.2$ & $11.5^{\mathrm{a}} \pm 0.2$ & $11.6^{\mathrm{ab}}{ }_{\mathrm{A}} \pm 0.2$ \\
& 60 & $658.2^{\mathrm{a}} \pm 1.7$ & $16.6^{\mathrm{a}} \pm 0.7$ & $306.0^{\mathrm{a}} \pm 0.9$ & $10.6^{\mathrm{a}} \pm 0.1$ & $9.7^{\mathrm{a}} \pm 0.1$ \\
Biceps femoris & 100 & $573.4^{\mathrm{b}}{ }_{\mathrm{A}} \pm 7.6$ & $16.5^{\mathrm{a}} \pm 3.3$ & $363.5^{\mathrm{b}} \pm 1.0$ & $11.5^{\mathrm{a}} \pm 0.3$ & $12.7^{\mathrm{b}}{ }_{\mathrm{A}} \pm 0.6$ \\
& 10 & $655.8^{\mathrm{a}} \pm 11.2$ & $16.6^{\mathrm{a}} \pm 1.4$ & $312.5^{\mathrm{a}} \pm 2.0$ & $12.2^{\mathrm{a}} \pm 0.5$ & $8.4^{\mathrm{ac}}{ }_{\mathrm{B}} \pm 0.5$ \\
& 60 & $662.8^{\mathrm{a}} \pm 7.9$ & $11.6^{\mathrm{a}} \pm 2.5$ & $301.8^{\mathrm{a}} \pm 14.3$ & $10.6^{\mathrm{a}} \pm 0.5$ & $11.0^{\mathrm{b}} \pm 0.2$ \\
\hline
\end{tabular}

Different small letters in columns indicate significant differences between means for one muscle comparing steam saturation level. Different capital letters in columns indicate significant differences between muscles at the same saturation level.

correlation detected between fat content and hardness neither in ST nor in BF muscle. Juiciness is related to the water content in cooked meat and is described as the amount and rate of juices released during mastication (Szczesniak, 2002). It is also connected with the cooking yield which is a critical factor for the industry. There are water soluble vitamins which may be lost with expelled juices and which are not heat resistant (Szterk et al., 2012). Some of the nutrients may be lost simply by heating as they would be heat labile, but additional losses may occur due to long term boiling or steaming treatments (Kondjoyan et al., 2014). As in this study the heating was quite short, one may assume that the vitamin losses were not large. The lower water content at $100 \%$ saturation level was rather surprising as we were suspecting that higher steam concentration in the oven chamber would allow to keep the water in a product. It was connected with very high cook losses observed at the same saturation level for both muscles (Table 2). They were significantly higher than at 10 and $60 \%$ steam injection level for ST and comparing to $10 \%$ injection for BF. It is possible that $100 \%$ vapour injection level treatment resembles boiling method which usually results in high cook losses. Baublits et al. (2006) comparing three beef muscles heated in convection-oven obtained the cook loss at the level of $32 \%$ in biceps femoris muscle, which is comparable to the amounts presented in this study at $10 \%$ saturation level. However, the maximum internal temperature the muscles were heated to was $70^{\circ} \mathrm{C}$, which is lower than it was in this study and the cooler heating conditions
Table 2. Effect of steam saturation level and muscle type on cooking losses (mean values \pm standard errors)

\begin{tabular}{ccc}
\hline Muscle type & $\begin{array}{c}\text { Steam saturation } \\
\text { level, \% }\end{array}$ & Cook losses, \% \\
\hline Semitendinosus & 10 & $36.12^{\mathrm{a}} \pm 0.39$ \\
& 60 & $36.83^{\mathrm{a}} \pm 0.53$ \\
Biceps femoris & 100 & $44.97^{\mathrm{b}}{ }_{\mathrm{A}} \pm 0.28$ \\
& 10 & $32.27^{\mathrm{a}} \pm 1.09$ \\
& 60 & $35.50^{\mathrm{ab}} \pm 2.08$ \\
& 100 & $39.43^{\mathrm{b}}{ }_{\mathrm{B}} \pm 1.39$ \\
\hline
\end{tabular}

Explanation as in Table 1.

allow to gain higher yields. In other words: an increase of heating temperature causes an increase of cook losses (Palka, 2003). The external parts of meat during boiling are not denatured as quickly as it happens during roasting and the moist is not kept inside the piece of meat. Vittadini et al. (2005) reported that during heating of meat in convection/steam oven the surface crust was not developed. However, in their study the vapour present in the oven kept the product moist. Kerth et al. (2003) suggested that if the piece of meat is placed on a tray and is soaked in the juice that is produced during cooking, it is possible that the cooking yields would be higher. Such cooking technique did not cause any decrease in cook losses observed in our study. 
Zając, M., Kącik, S., Palka, K., Widurek, P. (2015). Variable effect of steam injection level on beef muscles: semitendinosus and biceps femoris cooked in convection-steam oven. Acta Sci. Pol. Technol. Aliment., 14(4), 303-312. DOI: 10.17306/J.AFS.2015.4.31

The collagen amounts also varied depending on muscle and heating procedure. There was more of that protein in ST cooked in $100 \%$ vapour, which was the least moist and the collagen content was the lowest at $60 \%$ of vapour injection when the highest water content was noted. Whereas in BF no such tendency was observed. The collagen content is related with tenderness and chewiness. Its levels may vary depending on the muscle, if it is analysed in raw muscle, but it may be different when compared in the same muscle after heating. It is believed that the collagen solubility is even more important for texture than total amounts of that protein (Jeremiach et al., 2003). There are works showing that the collagen solubility or its total amount may affect the texture depending on the muscle which is analysed (Young and Braggins, 1993; Zając et al., 2011). In our study the insoluble collagen share was analysed in all samples and the results are presented on Figure 1. The insoluble collagen content was directly proportional to the steam saturation level in both muscles. However, the significant differences were noted only between 10 and $100 \%$ steam injection.

\section{Texture profile analysis}

Table 3 illustrates the results of texture profile analysis (TPA) conducted on steaks cooked in convectionsteam oven at various steam saturation levels. One of the most important factors that are assessed by this analysis is hardness, which is very well correlated with tenderness evaluated by sensory panel (Huidobro et al., 2003; Szczesniak, 2002). The hardness was lower in ST muscle comparing to BF at all steam saturation levels. Those differences were statistically significant. BF muscle was harder when cooked at $100 \%$ steam conditions in the oven chamber. It was also more chewy than the steaks cooked at 10 or $60 \%$ of steam injection. There was a lower hardness value observed for ST muscle at $10 \%$ saturation level in comparison with 60 and $100 \%$ saturation levels. Similarly, the same muscle was slightly less chewy at $10 \%$ saturated level, but there was no significant differences obtained after statistical analysis. The springiness of the samples was not changed by the steam level. There were differences however between muscles at the same saturation level. This parameter was generally higher in ST especially

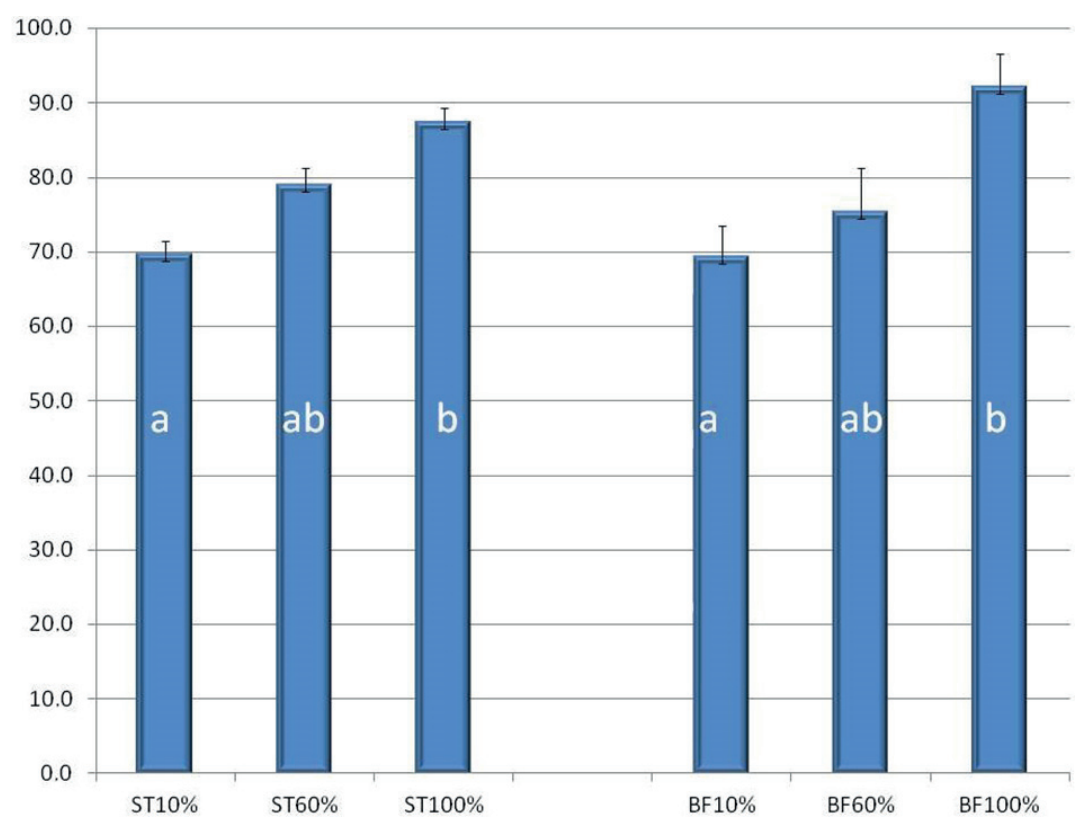

Fig. 1. Effect of muscle type and steam saturation level on insoluble collagen content, \% of total collagen: ST - semitendinosus, BF - biceps femoris. Mean values \pm standard errors. Different letters indicate significant differences between means for one muscle comparing steam saturation level 
Zając, M., Kącik, S., Palka, K., Widurek, P. (2015). Variable effect of steam injection level on beef muscles: semitendinosus and biceps femoris cooked in convection-steam oven. Acta Sci. Pol. Technol. Aliment., 14(4), 303-312. DOI: 10.17306/J.AFS.2015.4.31

Table 3. Effect of steam saturation level and muscle type on TPA parameters (mean values \pm standard errors)

\begin{tabular}{lcccccc}
\hline & \multicolumn{5}{c}{ Stem injection level, $\%$} \\
\cline { 2 - 6 } TPA parameters & 10 & 60 & 100 & 10 & 60 & 100 \\
\cline { 2 - 7 } & \multicolumn{5}{c}{ semitendinosus } \\
\cline { 2 - 7 } Hardness, N & $58.5^{\mathrm{a}}{ }_{\mathrm{A}} \pm 1.2$ & $86.3^{\mathrm{b}} \pm 2.2$ & $83.3^{\mathrm{b}}{ }_{\mathrm{A}} \pm 4.8$ & $128.9^{\mathrm{a}} \pm 12.4$ & $123.5^{\mathrm{a}}{ }_{\mathrm{B}} \pm 3.2$ & $176.3^{\mathrm{b}} \pm 7.1$ \\
Chewiness, N & $16.4^{\mathrm{a}}{ }_{\mathrm{A}} \pm 0.4$ & $21.5^{\mathrm{a}} \pm 2.0$ & $20.7^{\mathrm{a}}{ }_{\mathrm{A}} \pm 1.0$ & $25.1^{\mathrm{a}}{ }_{\mathrm{B}} \pm 2.6$ & $23.2^{\mathrm{a}} \pm 1.3$ & $32.7^{\mathrm{b}} \pm 2.0$ \\
Springness & $0.50^{\mathrm{a}}{ }_{\mathrm{A}} \pm 0.01$ & $0.43^{\mathrm{a}} \pm 0.02$ & $0.46^{\mathrm{a}}{ }_{\mathrm{A}} \pm 0.02$ & $0.37^{\mathrm{a}}{ }_{\mathrm{B}} \pm 0.01$ & $0.37^{\mathrm{a}} \pm 0.02$ & $0.38^{\mathrm{a}}{ }_{\mathrm{B}} \pm 0.02$ \\
Cohesivness & $0.56^{\mathrm{a}} \pm 0.01$ & $0.50^{\mathrm{a}} \pm 0.01$ & $0.51^{\mathrm{a}} \pm 0.02$ & $0.51^{\mathrm{a}} \pm 0.01$ & $0.50^{\mathrm{a}} \pm 0.01$ & $0.48^{\mathrm{a}} \pm 0.03$ \\
Adhessivness & $-0.34^{\mathrm{a}} \pm 0.03$ & $-1.55^{\mathrm{b}} \pm 0.04$ & $-1.1^{\mathrm{ab}} \pm 0.01$ & $-1.2^{\mathrm{a}} \pm 0.04$ & $-0.6^{\mathrm{a}} \pm 0.02$ & $-0.6^{\mathrm{a}} \pm 0.02$ \\
Resilience & $0.21^{\mathrm{a}} \pm 0.02$ & $0.17^{\mathrm{a}} \pm 0.01$ & $0.18^{\mathrm{a}} \pm 0.001$ & $0.21^{\mathrm{a}} \pm 0.01$ & $0.20^{\mathrm{a}} \pm 0.01$ & $0.20^{\mathrm{a}} \pm 0.01$ \\
\hline
\end{tabular}

Explanation as in Table 1.

in the case of 10 and $100 \%$ humidity level where it was significantly higher comparing to BF. The adhesion was not changed after applying different steam cooking conditions except from the sample of ST cooked with $60 \%$ of steam in the oven chamber which was more adhesive than the same muscle cooked at $10 \%$ of steam. There were no other differences detected in the texture parameters. Changing the steam injection level had no effect on resilience or cohesiveness of the samples. According to Palka (2003) those parameters change with the temperature to which the meat is heated, but they are not influenced by ageing time.
The ageing time improved the texture parameters as it was expected. In both muscles hardness, chewiness and adhesiveness were lower after storing the raw material in cool conditions (Table 4). However, comparing the texture results obtained after ageing to those received after cooking the steaks at various steam injection levels, we found some very interesting relations. The hardness value of ST muscle cooked after ageing at $100 \%$ steam saturation level was comparable to the hardness value of non-aged ST muscle cooked at $10 \%$ saturation level. This finding indicates that cooking in convection oven with $10 \%$ saturation

Table 4. Effect of ageing time on TPA parameters of steaks cooked in convection oven at $100 \%$ humidity level (mean values \pm standard errors)

\begin{tabular}{|c|c|c|c|c|}
\hline \multirow{3}{*}{ TPA parameters } & \multicolumn{4}{|c|}{ Ageing time } \\
\hline & $2^{\text {nd }}$ day & $10^{\text {th }}$ day & $2^{\text {nd }}$ day & $10^{\text {th }}$ day \\
\hline & \multicolumn{2}{|c|}{ semitendinosus } & \multicolumn{2}{|c|}{ biceps femoris } \\
\hline Hardness, N & $89.1_{\mathrm{A}}^{\mathrm{a}} \pm 6.2$ & $64.6^{\mathrm{a}}{ }_{\mathrm{A}} \pm 2.6$ & $182.2^{\mathrm{a}}{ }_{\mathrm{B}} \pm 9.9$ & $25.3^{\mathrm{b}}{ }_{\mathrm{B}} \pm 2.6$ \\
\hline Chewiness, $\mathrm{N}$ & $22.3^{\mathrm{a}}{ }_{\mathrm{A}} \pm 1.4$ & $16.0^{\mathrm{a}}{ }_{\mathrm{A}} \pm 0.6$ & $32.7^{\mathrm{a}} \pm 2.6$ & $7.4^{\mathrm{b}}{ }_{\mathrm{B}} \pm 0.8$ \\
\hline Springness & $0.49 \pm 0.02$ & $0.49 \pm 0.01$ & $0.4_{\mathrm{A}} \pm 0.05$ & $0.5_{\mathrm{B}} \pm 0.0 .05$ \\
\hline Cohesivness & $0.5 \pm 0.02$ & $0.5 \pm 0.01$ & $0.5 \pm 0.03$ & $0.5 \pm 0.02$ \\
\hline Adhessivness & $-1.1 \pm 0.01$ & $-0.3 \pm 0.02$ & $-2.2 \pm 0.05$ & $-0.6 \pm 0.02$ \\
\hline Resilience & $0.18 \pm 0.01$ & $0.19 \pm 0.004$ & $0.20 \pm 0.01$ & $0.22 \pm 0.01$ \\
\hline
\end{tabular}

Explanation as in Table 1. 
Zając, M., Kącik, S., Palka, K., Widurek, P. (2015). Variable effect of steam injection level on beef muscles: semitendinosus and biceps femoris cooked in convection-steam oven. Acta Sci. Pol. Technol. Aliment., 14(4), 303-312. DOI: 10.17306/J.AFS.2015.4.31

level allows to obtain the results as after 10 days of ageing. Unfortunately it was only in the case of ST muscle. BF on the other hand was much more tender and less chewy after ageing comparing to all vapour levels that were applied on non-aged steaks.

\section{Colour assessment}

Colour determination results for samples cooked at different vapour levels are presented in Table 5. The effect of steam injection level varied depending on the muscle analysed. In ST the increase of the steam concentration caused the decrease of lightness ( $\mathrm{L}^{*}$ value) and the increase of the red colour ( $\mathrm{a}^{*}$ value). Those two parameters are considered to be the most informative in meat colour evaluation (Mielnik and Slinde, 1983). The yellowness value $\left(\mathrm{b}^{*}\right)$ was lower in steaks cooked at $60 \%$ vapour saturation comparing to 10 and $100 \%$ steam level. BF muscle was generally darker than ST, which was confirmed in other studies (Grześkowiak et al., 2002). In this muscle (BF) there was no effect of steam saturation level on steaks' lightness or red colour values. Stakes cooked with $100 \%$ saturation level were more yellow $\left(b^{*}\right)$ than those cooked with $10 \%$ vapour concentration. The $\mathrm{a}^{*}$ values obtained for ST muscle were lower at $10 \%$ steam saturation level comparing to 60 and $100 \%$ and generally all ST samples were slightly less red in colour comparing to BF. ST samples cooked with 10 and $100 \%$ of steam injection were significantly more yellow comparing to those cooked with $60 \%$ of steam saturation. As the visible colour changes are more important from consumers' point of view, the $\Delta \mathrm{E}$ values were calculated. The colour modifications measured instrumentally can be considered as noticeable visual changes when the total colour difference values are between 2 and 3.5. If they are higher than 3.5 they are clearly visible. These are values which were evaluated and accepted by Commission Internationale de l'Eclairage (CIE) (Colour..., 1999). Comparing two muscles used in this work, we found that the steam saturation level did not have any influence on BF muscle whereas in case of ST the effect was significant for all vapour concentrations applied. The absolute colour differences referred to as delta $E$ values were in range from 0.75 to 1.35 in the case of BF and from 2.73-6.45 for ST. The highest value was obtained in comparison of ST cooked with 10 and $60 \%$ of steam concentration in the oven chamber.

The effect of variable steam injection level was different on each analysed beef muscle. M. biceps femoris was harder and more chewy at $100 \%$ steam application level whereas for $m$. semitendinosus the hardness values were significantly lower at $10 \%$ saturation level comparing to 60 and $100 \%$. There was no visible influence on the appearance of analysed $m$. biceps femoris steaks while in the case of $m$. semitendinosus there were significant differences in colour between steaks cooked at various steam injection levels. Thus, this is a clear evidence, that there should be different conditions applied for different meat cuts. There were also some similarities noted. The 100\% steam saturation level caused the significant increase of cook losses in both muscles, which is an important feature from economical point of view. This is also a disadvantage for consumers as higher cook losses are usually related to

Table 5. Effect of steam saturation level and muscle type on colour (CIE L*a*b*) (mean values \pm standard errors)

\begin{tabular}{ccccc}
\hline Muscle type & Steam saturation level, \% & L $^{*}$ value & $\mathrm{a}^{*}$ value & $\mathrm{b}^{*}$ value \\
\hline Semitendinosus & 10 & $63.41^{\mathrm{a}}{ }_{\mathrm{A}} \pm 0.04$ & $1.27^{\mathrm{a}} \pm 0.06$ & $14.15^{\mathrm{a}}{ }_{\mathrm{A}} \pm 0.06$ \\
& 60 & $57.30^{\mathrm{b}}{ }_{\mathrm{A}} \pm 0.10$ & $2.60^{\mathrm{b}} \pm 0.16$ & $12.82^{\mathrm{b}} \pm 0.11$ \\
Biceps femoris & 100 & $59.47_{\mathrm{A}}^{\mathrm{b}} \pm 0.14$ & $2.43^{\mathrm{b}} \pm 0.14$ & $14.45^{\mathrm{a}}{ }_{\mathrm{A}} \pm 0.13$ \\
& 10 & $55.60_{\mathrm{B}}^{\mathrm{a}} \pm 0.19$ & $2.95^{\mathrm{a}}{ }_{\mathrm{B}} \pm 0.07$ & $12.25_{\mathrm{B}}^{\mathrm{a}} \pm 0.16$ \\
& 60 & $54.34_{\mathrm{B}}^{\mathrm{a}} \pm 0.37$ & $3.21^{\mathrm{a}} \pm 0.05$ & $12.67^{\mathrm{ab}} \pm 0.17$ \\
\hline
\end{tabular}

Explanation as in Table 1. 
Zając, M., Kącik, S., Palka, K., Widurek, P. (2015). Variable effect of steam injection level on beef muscles: semitendinosus and biceps femoris cooked in convection-steam oven. Acta Sci. Pol. Technol. Aliment., 14(4), 303-312. DOI: 10.17306/J.AFS.2015.4.31

lower juiciness and a loss of nutrients. There was also a significant increase of the insoluble collagen fraction found, which was proportional to the increase of vapour concentration in the oven chamber. However, in this study it was hardly related to texture values. In the study by Chiavaro et al. (2009) it was concluded that cooking the pork meat in convection oven with steam, lowers the cooking time, but increases hardness and paleness of samples. There were also higher cook losses observed. In other studies (Mora et al., 2011) the negative influence of high steam cooking conditions on tenderness evaluated by sensory panel and general quality of turkey meat was reported. On the other hand, Bowers et al. (2012) analysing beef roasts confirmed the advantages of convection steam ovens that are described by the producers. They suggested that those ovens may improve the tenderness and cooking yields. However, it was also proved in our study that the effects are muscle dependent and that for some muscles it would be preferable not to apply the moist heating technique. The results of our study are another example showing, that it is very hard to predict the general quality of meat product even if there are similar conditions applied (Kondjoyan et al., 2014).

\section{CONCLUSIONS}

The recommendation for caterers resulting from our study would be an application of 10\% saturation level for $m$. semitendinosus muscle as it is the most tender and cooking losses are the lowest what is connected with juiciness. The hardness of the steaks cooked at the conditions is comparable with the hardness of steaks which were stored for 10 days. The cooking losses were also comparable. After 10-day storage the cooking losses were $39.7 \%$ and $36.12 \%$ when cooked after 2 days at $10 \%$ humidity level. However, for the same reasons, the steaks obtained from biceps femoris muscle should be cooked at maximum $60 \%$ steam saturation level, but longer cool storage time of those cuts is still recommended.

\section{REFERENCES}

Awuah, G., Ramaswamy, H., Economides, A. (2007). Thermal processing and quality: Principles and overview. Chem. Eng. Proc., 46(6), 584-602.
Barbanti, D., Pasquini, M. (2005). Influence of cooking conditions on cooking loss and tenderness of raw and marinated chicken breast meat. LWT-Food Sci. Techn., 38(8), 895-901.

Baublits, R., Brown, A., Pohlman, F., Rule, D., Johnson, Z., Onks, D., ..., Pugh, R. (2006). Fatty acid and sensory characteristics of beef from three biological types of cattle grazing cool-season forages supplemented with soyhulls. Meat Sci., 72(1), 100-107.

Blodgett (n.d.). Retrieved 2013 from from http://www. blodgett.com/products/combi/

Bowers, L., Dikeman, M., Murray, L., Stroda, S. (2012). Cooked yields, color, tenderness, and sensory traits of beef roasts cooked in an oven with steam generation versus a commercial convection oven to different endpoint temperatures. Meat Sci., 92(2), 97-106.

Campo, M., Santolaria, P., Sanudo, C., Lepetit, J., Olleta, J., Panea, B., Alberti, P. (2000). Assessment of breed type and ageing time effects on beef meat quality using two different texture devices. Meat Sci., 55(4), 371-378.

Chiavaro, E., Rinaldi, M., Vittadini, E., Barbanti, D. (2009). Cooking of pork Longissimus dorsi at different temperature and relative humidity values: Effects on selected physico-chemical properties. J. Food Eng., 93(2), 158-165.

Colour and quality. (1999). Heidelberg Druckmaschinen AG, Kurfursten-Anlage, 52-60.

Dastro (n.d.). Retrieved 2013 from http://www.dastro.pl/ sklep/a3m2dora/shop/3---Piece-konwekcyjno-parowe. html

Diakun, J., Zawisza, K. (2006). Zużycie moralne pieców konwekcyjno-parowych [Normal wear of convectioncum-vapour furnaces]. Inż. Roln., 7(82), 83-89 [in Polish].

Campo, M., Santolaria, P., Sanudo, C., Lepetit, J., Olleta, J., Panea, B., Alberti, P. (2003). Assessment of the relationship between chemical components and palatability of major beef muscles and muscle groups. Meat Sci., 65, 2013-1019.

Grześkowiak, E., Borzuta, K., Wichłacz, H., Strzelecki, J. (2002). Sensory traits of 13 culinary cuts obtained from carcasses of Young Black-and-White slaughter cattle. Anim. Sci. Pap. Rep., 20(suppl. 1), 179-186.

Guzek, D., Głąbska, D., Wierzbicka, A. (2012). Porównanie możliwości prognozowania barwy łopatki wołowej dla różnych metod obróbki cieplnej [Comparison of possibilities of prediction of beet blade colour for various methods of thermal treatment]. Post. Nauki Techn., 13, 61-68 [in Polish]. 
Zając, M., Kącik, S., Palka, K., Widurek, P. (2015). Variable effect of steam injection level on beef muscles: semitendinosus and biceps femoris cooked in convection-steam oven. Acta Sci. Pol. Technol. Aliment., 14(4), 303-312. DOI: 10.17306/J.AFS.2015.4.31

Hobart (n.d.). Retrieved 2013 from http://www.hobartcorp. com/products/cooking/combi-ovens-and-barcode-scanners/

Huidobro de, F., Miguel, E., Onega, E., Blazquez, B. (2003). Changes in meat quality characteristics of bovine meat during the first 6 days post mortem. Meat Sci., 65(4), $1439-1446$.

Jeremiach, L. (1996). The influence of subcutaneous fat thickness and marbling on beef. Palatability and consumer acceptance. Food Res. Int., 29, 513-520.

Kerth, C. R., Blair-Kerth, L. K., Jones, W. R. (2003). Warner-Bratzler Shear Force Repeatability in Beef Longissimus Steaks Cooked With a Convection Oven, Broiler, or Clam-shell Grill. J. Food Sci. 68, 2, 668-669.

Kondjoyan, A., Kohler, A., Realini, C., Portanguen, S. Kowalski, R., Clerjon, S., ..., Debrauwer, L. (2014). Towards models for the prediction of beef meat quality during cooking. Meat Sci., 97(3), 323-331.

Kosiecka-Gębska, M., Przeździecka, N., Gębski, J. (2010). Tendencje zmian w spożyciu mięsa wołowego w Polsce w latach 2000-2009 [Trends of changes in beef consumption in Poland in 2000-2009]. Zesz. Nauk. SGGW, 10(25)(2), 49-59 [in Polish].

Mielnik, J., Slinde, E. (1983). Sausage color measured by integrating sphere reflectance spectrophotometry when whole-blood or blood cured by nitrite is added to sausages. J. Food Sci., 48(6), 1723-1725.

Modzelewska-Kapitula, M., Dąbrowska, E., Jankowska, B., Kwiatkowska, A., Cierach, M. (2012). The effect of muscle, cooking method and final internal temperature on quality parameters of beef roast. Meat Sci., 91(2), 195-202.

Monson, F., Sanudo, C., Sierra, I. (2005). Influence of breed and ageing time on the sensory meat quality and consumer acceptability in intensively reared beef. Meat Sci., 71(3), 471-479.

Mora, B., Curti, E., Vittadini, E., Barbanti, D. (2011). Effect of different air/steam convection cooking methods on turkey breast meat: Physical characterization, water status and sensory properties. Meat Sci., 88(3), 489-497.

Palka, K. (2000). Roasting-induced changes in texture and fibre microstructure of bovine semitendinosus muscle. Polish J. Food Nutr. Sci., 90/5(2), 41-45.

Palka, K. (2003). The influence of post-mortem ageing and roasting on the microstructure, texture and collagen solubility of bovine semitendinosus muscle. Meat Sci., 64(2), 191-198.

PN-75/A-04018. Produkty rolniczo-żywnościowe: Oznaczanie azotu metodą Kjeldahla i przeliczanie na białko [Agri-food products: The analysis of nitrogen content by Kjeldahl method and protein calculation; in Polish].

PN-ISO 936:2000. Mięso i przetwory mięsne. Oznaczanie zawartości popiołu całkowitego [Meat and meat products. Determination of total ash; in Polish].

PN-ISO 1442:2000. Mięso i przetwory mięsne. Oznaczanie zawartości wody [Meat and meat products. Determination of moisture content; in Polish].

PN-ISO 1444:2000. Mięso i przetwory mięsne. Oznaczanie zawartości tłuszczu wolnego [Meat and meat products. Determination of free fat content; in Polish].

PN-ISO 3496:2000. Mięso i przetwory mięsne. Oznaczanie zawartości hydroksyproliny [Meat and meat products. Determination of hydroxyproline content; in Polish].

Szczesniak, A. (2002). Texture is a sensory property. Food Qual. Prefer., 13(4), 215-225.

Szterk, A., Roszko, M., Malek, K., Kurek, M., Zbiec, M., Waszkiewicz-Robak, B. (2012). Profiles and concentrations of heterocyclic aromatic amines formed in beef during various heat treatments depend on the time of ripening and muscle type. Meat Sci., 92(4), 587-595.

Verbeke, W. (2009). Market differentiation potential of country-of-origin, quality and traceability labeling. Estey Centr. J. Int. Law Trade Policy, 10(1), 20-35.

Vittadini, E., Rinaldi, M., Chiavaro, E., Barbanti, D., Massini, R. (2005). The effect of different convection cooking methods on the instrumental quality and yield of pork Longissimus dorsi. Meat Sci., 69(4), 749-756.

Young, O., Braggins, T. (1993). Tenderness of ovine samimambranosus - is collagen concentration or solubility the critical factor. Meat Sci., 35(2), 213-222.

Zając, M., Midura, A., Palka, K., Węsierska, E., Krzysztoforski, K. (2011). Skład chemiczny, rozpuszczalność kolagenu śródmięśniowego i tekstura wybranych mięśni wołowych [Chemical composition, solubility of intramuscular collagen, and texture of selected beef muscles]. Żywn. Nauka Techn. Jakość, 4(77), 103-116 [in Polish].

Zhuang, H., Savage, E. (2008). Validation of a combi oven cooking method for preparation of chicken breast meat for quality assessment. J. Food Sci., 73(8), S424-S430. 
Zając, M., Kącik, S., Palka, K., Widurek, P. (2015). Variable effect of steam injection level on beef muscles: semitendinosus and biceps femoris cooked in convection-steam oven. Acta Sci. Pol. Technol. Aliment., 14(4), 303-312. DOI: 10.17306/J.AFS.2015.4.31

\section{ZRÓŻNICOWANY WPŁYW POZIOMU INIEKCJI PARY WODNEJ NA MIĘŚNIE BYDLĘCE: SEMITENDINOSUS I BICEPS FEMORIS OGRZEWANE W PIECU KONWEKCYJNO-PAROWYM}

\section{STRESZCZENIE}

Wstęp. Piece konwekcyjno-parowe są często używane do podgrzewania żywności w restauracjach. Zgodnie z deklaracjami producentów nadają się do gotowania porcji mięsa, które są bardziej kruche i smaczne w porównaniu z otrzymywanymi konwencjonalnymi metodami gotowania.

Materiał i metody. Steki wołowe z mięśni semitendinosus i biceps femoris ogrzewano w piecu konwekcyjno-parowym z zastosowaniem trzech różnych poziomów iniekcji pary wodnej: 10, 60 i 100\%. W pracy analizowano skład chemiczny, uwzględniając zawartość kolagenu ogółem oraz nierozpuszczalnego, ubytki cieplne oraz teksturę i parametry barwy.

Wyniki. M. biceps femoris był najtwardszy i najbardziej żujny przy 100-procentowym nasyceniu komory pieca parą wodną, a twardość mięśnia $m$. semitendinosus była najmniejsza przy 10-procentowej iniekcji pary. Zmiana warunków zaparowania komory pieca nie wpłynęła na wykrywalne gołym okiem zmiany barwy w porcji z mięśnia $m$. biceps femoris, ale była znacząca dla m. semitendinosus. Zastosowanie 100-procentowego nasycenia parą wodną spowodowało większe straty cieplne i zwiększenie udziału frakcji kolagenu nierozpuszczalnego w obu mięśniach.

Wnioski. Wyniki pokazują, że warunki ogrzewania powinny być dostosowane indywidualnie do rodzaju mięśnia i w tym kontekście mogą być korzystne dla restauratorów używających pieców konwekcyjno-parowych. Kruchość mięśnia $m$. semitendinosus ogrzewanego w 10-procentowym nasyceniu parą była porównywalna z kruchością uzyskaną w tym samym mięśniu poddanym procesowi 10-dniowego dojrzewania i ogrzewania przy 100-procentowym nasyceniu parą wodną. W celu uzyskania optymalnej kruchości steki $\mathrm{z}$ mięśnia $m$. biceps femoris powinny być ogrzewane z zastosowaniem nasycenia parą maksymalnie $60 \%$.

Słowa kluczowe: wołowina, piec konwekcyjno-parowy, jakość mięsa, kruchość, barwa

Received - Przyjęto: 31.07.2015

Accepted for print - Zaakceptowano do druku: 7.09.2015

For citation - Do cytowania

Zając, M., Kącik, S., Palka, K., Widurek, P. (2015). Variable effect of steam injection level on beef muscles: semitendinosus and biceps femoris cooked in convection-steam oven. Acta Sci. Pol. Technol. Aliment., 14(4), 303-312. DOI: 10.17306/J.AFS.2015.4.31 